\title{
Kinerja Keuangan dan Faktor Ekonomi Makro sebagai Penentu Return Saham Perusahaan pada Jakarta Islamic Index
}

\author{
Ressy Thusda Permala ${ }^{1}$, Arles P. Ompusunggu ${ }^{2}$ \\ 1.2 Universitas Pancasila, Jl. Srengseng Sawah, Jagakarsa, Jakarta Selatan, 12640
}

\section{INFO ARTIKEL \\ JEL Classsification: \\ E44 \\ L16}

Keywords:

earning per share, exchange rates,

inflation, interest rates, product domestic

bruto, return on

investment, stock return.

\begin{abstract}
$A B S T R A C T$
The purpose of this study is to analyze the effect of return on investment, earnings per share, interest rate, exchange rate, inflation and gross domestic product on stock returns in Indonesia Stock Exchange. The sample used were 9 issuers registered in the Jakarta Islamic Index during the period of 20082014. The analysis was done by multiple regression test. The results showed that the exchange rate and the gross domestic product had a significant effect on stock return, while return on investment, earnings per share, interest rate, and inflation had no effect. Based on the results of research macroeconomic factors determining stock returns on samples tested are the exchange rate and gross domestic product, but interest rates and inflation have no effect. The same is true in earnings per share and operational performance also does not affect stock returns.
\end{abstract}

\begin{abstract}
A B S T R A K
Tujuan penelitian ini adalah untuk menganalisis pengaruh return on investment, earning per share, suku bunga, kurs, inflasi dan product domestic bruto terhadap return saham di Bursa Efek Indonesia. Sampel yang digunakan sebanyak 9 emiten yang terdaftar dalam Jakarta Islamic Index selama periode 2008-2014. Analisis dilakukan dengan uji regresi berganda. Hasil penelitian menunjukkan bahwa kurs dan product domestic bruto berpengaruh signifikan terhada return saham, sedangkan return on investment, earning per share, suku bunga, dan inflasi tidak berpengaruh. Berdasarkan hasil penelitian faktor ekonomi makro penentu return saham pada sampel yang diuji adalah kurs dan product domestic bruto, tetapi suku bunga dan inflasi tidak berpengaruh. Hal yang sama terbukti pada laba per saham dan kinerja operasional juga tidak mempengaruhi return saham.
\end{abstract}

\section{Pendahuluan}

Kondisi di pasar saham, dari awal 2008 hingga tanggal 24 Desember 2008, menunjukkan penurunan IHSG sekitar 51 persen dari 2745,85 menjadi 1336,61, indeks LQ 45 turun sekitar 55 persen dari 599,82 menjadi 265,34, sementara indeks Jakarta Islamic Index (JII) turun sekitar 56 persen dari 493,01 menjadi 215,97. JII turun terendah, setelah pada 2007 meningkat tajam akibat kenaikan saham sektor komoditi hingga pertengahan 2008. Komposisi sektor komoditas dalam perhitungan IHSG, LQ45 maupun JII, juga menjadi salah satu pemicu terbesar penurunan indeks.

Return saham merupakan kandidat yang baik sebagai indikator penting dalam perekonomian. Pasar modal salah satu representasi

*Email Korespondensi: 'juang_82@yahoo.com, ${ }^{2}$ indotaxsolution@gmail.com 
dari perkembangan perekonomian suatu negara, dimana hampir semua industri yang ada di dalam suatu negara terwakili di dalam pasar modal.(Tangjitprom,2012). Instrumen berbasis syariah di pasar modal Indonesia sangat diperlukan, mengingat penduduk Indonesia yang sebagian besar umat Islam. Produk pada pasar modal syariah yang paling dikenal masyarakat adalah saham. Pilihan investor terhadap saham perusahaan yang tergabung dalam saham syariah juga tidak terlepas dari adanya return yang diharapkan. Return saham non syariah mempunyai tingkat return yang lebih tinggi dibandingkan saham syariah. Hal ini menunjukkan bahwa saham syariah masih menghasilkan return yang rendah. (Andi,2012).

Perhitungan return tahunan pada JII dan IHSG menunjukkan bahwa nilai return yang diberikan indeks JII yaitu 10 persen, lebih rendah dibandingkan return yang diberikan IHSG sebesar 14 persen. Perhitungan simpangan dari pergerakan harga saham pada indeks JII yaitu sebesar 8,26 persen lebih besar dibandingkan pada indeks IHSG yaitu sebesar 7,66 persen. Secara umum hal ini menunjukkan resiko pada indeks JII lebih besar dibandingkan indeks IHSG, walaupun return indeks JII lebih rendah dibandingkan indeks IHSG. (Pratiti,2014).

Return saham emiten yang terdaftar dalam Jakarta Islamic Index periode 2007-2008 dapat terlihat pada gambar 1.1 berikut ini :
Saham syariah yang terdaftar dalam Jakarta Islamic Index (JII) yang merupakan saham pilihan tidak otomatis memberikan return saham yang positif. Pada periode krisis ekonomi yaitu periode 2008 dan 2013, mayoritas saham emiten JII memberikan return saham negatif. (Nur, 2013). Penurunan yang sangat signifikan terjadi pada periode 2008, dimana return saham syariah yang terdaftar dalam Jakarta Islamic Index (JII) mencapai titik terendah yaitu sebesar -277 persen.

Penelitian ini ingin mengungkap sejauh mana emiten yang terdaftar dalam Jakarta Islamic Index (JII) di Bursa Efek Indonesia mampu memberikan return saham yang optimal kepada investor melalui informasi intern. Pada penelitian ini informasi intern dibatasi hanya berupa Return on Investment (ROI) dan Earning per Share (EPS). Selain informasi intern, pada penelitian ini juga menggunakan informasi ekstern, berupa kondisi makro ekonomi, yang meliputi: suku bunga, kurs, inflasi dan Product Domestic Bruto (PDB).

\section{Telaah Teori dan Pengembangan Hipotesis}

Godfrey et al. (2006) mengatakan teori signal berbicara mengenai manajer yang menggunakan akun-akun dalam laporan keuangan untuk memberikan tanda atau signal harapan dan tujuan masa depan. Menurut teori

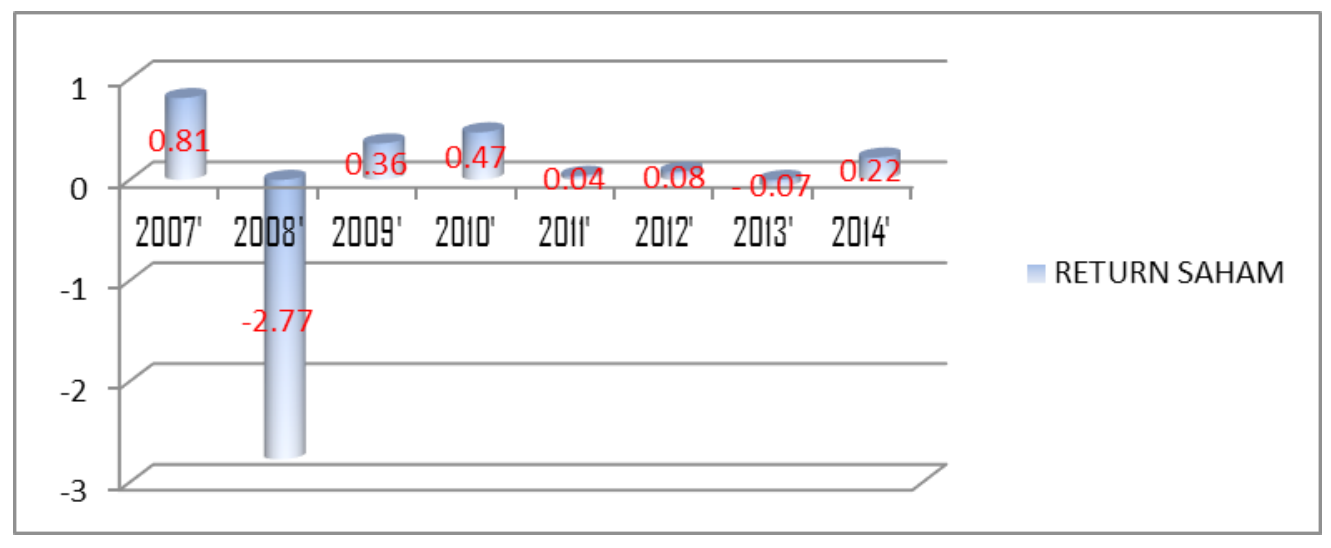

Sumber : Data yahoofinance yang diolah

Gambar 1. Return Saham Emiten Jakarta Islamic Index

Periode 2007 - 2014 
ini, jika manajer mengharapkan suatu tingkat pertumbuhan perusahaan yang tinggi di masa depan, mereka akan berusaha memberikan signal itu terhadap investor melalui akun-akun. Manajer dari perusahaan lain yang memiliki kinerja yang baik akan memiliki insentif yang sama, dan manajer dari perusahaan dengan kinerja rata-rata akan memiliki insentif untuk melaporkan berita yang positif sehingga mereka tidak dianggap berkinerja buruk.

\section{Pengaruh Return on Investment terhadap return saham}

Return on Investment (ROI) merupakan rasio yang digunakan untuk mengukur kemampuan perusahaan dalam menghasilkan keuntungan. ROI umumnya digunakan investor sebagai pedoman dalam membuat keputusan investasi. Perusahaan yang mampu menghasilkan laba yang besar dapat mendorong minat investor untuk menanamkan modaya di perusahaan tersebut, karena investor menganggap bahwa perusahaan yang mampu menghasilkan laba yang besar akan memberikan return atau deviden yang besar pula, sehingga dapat meningkatkan kekayaan investor (Kennedy,dkk,2009).

Pernyataan tersebut didukung oleh penelitian Yunita (2014) dan Harry (2010), yang menyatakan bahwa ROI berpengaruh terhadap return saham.

H1: Return on Investment berpengaruh terhadap return saham.

\section{Pengaruh Earning Per Share (EPS) terhadap Return Saham}

Husnan (2005:328) menyatakan bahwa alat ukur yang biasa dipakai investor untuk menilai tingkat profitabilitas suatu saham adalah Earning per Share (EPS). Investor seringkali memusatkan perhatian pada EPS dalam melakukan analisis, karena mencerminkan kombinasi dari berbagai faktor yang mempengaruhi tingkat keuntungan atau laba suatu perusahaan.

Penelitian Chen (2006), Vida (2006), Renzia (2007), Kurniawan (2013), Angraghini
(2014) mendukung pernyataan tersebut, dimana menunjukkan adanya pengaruh dari Earning per Share terhadap return saham.

H2: Earning per Share berpengaruh terhadap return saham.

\section{Pengaruh Suku Bunga (BI Rate) Terhadap Return Saham}

Menurut laporan perekonomian Indonesia (2005: 115), BI rate adalah suku bunga kebijakan moneter (policy rate) dengan tenor satu bulan yang leveya ditetapkan dalam Rapat Dewan Gubernur dan diumumkan pada publik oleh Bank Indonesia secara periodik untuk jangka waktu tertentu. Secara eksternal BI rate ini akan diacu oleh pelaku pasar dalam penetuan suku bunga Pasar Uang Antar Bank (PUAB), deposito dan kredit.

Penelitian Wongbangpo dan Sharma (2002), Suyanto (2007), Azwin (2010) S Mbulawa (2015), mendukung pernyataan bahwa suku bunga berpengaruh terhadap return saham.

H3: Suku bunga berpengaruh terhadap return saham.

\section{Pengaruh Kurs Terhadap Return Saham}

Menurut Mansur (2009), kurs valuta asing adalah salah satu alat pengukur yang digunakan dalam menilai kekuatan suatu perekonomian. Kurs menunjukkan banyaknya uang dalam negeri yang diperlukan untuk membeli satu unit valuta asing tertentu. Fluktuasi nilai tukar rupiah terhadap mata uang asing akan sangat mempengaruhi iklim investasi dalam negeri, terutama pasar modal.

Penelitian Subao (2009), Adjasi dkk (2008), Ratna (2009), Suskim dan Maria (2013), mendukung pernyataan tersebut dimana kurs berpengaruh terhadap return saham.

H4: Kurs berpengaruh terhadap return saham

\section{Pengaruh Inflasi Terhadap Return Saham}

Purnomo (2013:107) Inflasi adalah kondisi saat harga-harga barang / jasa secara umum 
mengalami kenaikan terus-menerus sehingga dapat menurunkan nilai mata uang di negara setempat. Inflasi yang tinggi akan berdampak pada lesunya perekonomian masyarakat maupun emiten yang ber-sangkutan, sehingga akan mengurangi kinerja keuangan perusahaan dan pada akhirnya akan menurunkan nilai return saham emiten yang bersangkutan.

Penelitian Ugur (2005), Ratna (2009), Yeh and Chi (2009), Nurhakim (2010), Agbaje (2013), mendukung pernyataan bahwa inflasi berpengaruh terhadap return saham.

H5: Inflasi berpengaruh terhadap return saham.

\section{Pengaruh Product Domestic Bruto (PDB) terhadap Return Saham}

Sukirno (2008) Product Domestic Bruto (PDB) dapat diartikan sebagai nilai barang dan jasa akhir yang dihasilkan oleh berbagai unit produksi di wilayah suatu negara dalam jangka waktu setahun. Produk Dometik Bruto perkapita seringkali dijadikan acuan sebagai pertimbangan untuk melihat perkembangan ekonomi suatu negara. Semakin tinggi PDB maka diasumsikan bahwa kegiatan perekonomian negara tahun tersebut mengalami peningkatan dan ini dapat dijadikan indikator akan adanya keuntungan untuk menanamkan saham atau membeli saham perusahaan - perusahaan yang terdaftar di bursa efek (Nurul,2013).

Pernyataan tersebut didukung oleh hasil penelitian Hokker (2004), Reddy (2012), Nazwar (2008), Zulbeti (2010), bahwa PDB berpengaruh terhadap return saham.

H6: PDB berpengaruh terhadap return saham.

Pengaruh Return on Investment (ROI), Earning per Share (EPS), Suku Bunga, Kurs, Inflasi, dan Product Domestic Bruto (PDB) Terhadap Return Saham.

Informasi internal tentang kinerja perusahaan yang dapat diketahui melalui return on investment (ROI) dan earning per share (EPS) sangat penting untuk di perhatikan dan tidak bisa diabaikan begitu saja terhadap return saham selain itu yang juga tidak kalah penting adalah informasi eksternal berupa suku bunga, kurs, inflasi, dan product domestic bruto (PDB).

Pernyataan tersebut sejalan dengan penelitian Yunita (2014) yang telah membuktikan bahwa ROI dan EPS berpengaruh terhadap return saham. M Khoirul (2013), menyimpulkan bahwa variabel ekonomi makro yang meliputi kurs, inflasi dan suku bunga berpengaruh terhadap return saham.

H7: Return on Investment (ROI), Earning per Share (EPS), suku bunga, kurs, inflasi, dan Product Domestic Bruto (PDB) secara simultan berpengaruh terhadap return saham.

Berikut adalah tabel rangkuman matrix riset tentang variabel independen (ROI, EPS, suku bunga, kurs, inflasi dan PDB yang berpengaruh signifikan dan berpengaruh tidak signifikan terhadap variabel dependen (return saham). 
Tabel 1. Rangkuman Matrix Riset tentang Return Saham

\begin{tabular}{|c|c|c|c|}
\hline \multirow{2}{*}{ No } & \multirow{2}{*}{$\begin{array}{l}\text { Variabel } \\
\text { Independen }\end{array}$} & \multicolumn{2}{|c|}{ Variabel Dependen } \\
\hline & & Berpengaruh Signifikan & Berpengaruh tidak Signifikan \\
\hline 1. & ROI & Harry (2010), Anggragini (2014). & $\begin{array}{l}\text { Harjono (2010), Getereida (2012), } \\
\text { Auliyah \& Hamzah (2006), Eka (2010). }\end{array}$ \\
\hline 2. & EPS & $\begin{array}{l}\text { Renzia (2007), Kurniawan (2013), } \\
\text { Virda (2006), Chen (2006). }\end{array}$ & Auliyah \& Hamzah (2006), Eka (2010). \\
\hline 3. & Suku Bunga & $\begin{array}{l}\text { Murti (2005), Wongbangpo dan Sharma } \\
\text { (2002), Suyanto (2007), Azwin (2010) } \\
\text { S Mbulawa (2015). }\end{array}$ & Sari (2012), Dheny (2014). \\
\hline 4. & Kurs & $\begin{array}{l}\text { Subao (2009), Adjasi dkk (2008), Ratna } \\
\text { (2009), Suskim dan Maria (2013). }\end{array}$ & Azwin\&Mirza (2010) \\
\hline 5. & Inflasi & $\begin{array}{l}\text { Ugur (2005), Ratna (2009), Yeh and } \\
\text { Chi (2009), Nurhakim (2010), Agbaje } \\
\text { (2013). }\end{array}$ & $\begin{array}{l}\text { Mariesa (2007), Sari, dkk (2012), Mia } \\
\text { (2010). }\end{array}$ \\
\hline 6. & PDB & $\begin{array}{l}\text { Hokker (2004), Reddy (2012), Nazwar } \\
\text { (2008), Zulbeti (2010). }\end{array}$ & Thobarry(2009). \\
\hline
\end{tabular}

\section{Metode}

Variabel penelitian ini enam variabel independen yaitu ROI, EPS, suku bunga, kurs, inflasi dan PDB, dimana variabel dependen adalah return saham. Dalam penelitian ini return saham diukur dengan selisih antara harga saham periode saat ini dengan harga saham pada periode sebelumnya dibagi dengan harga saham periode sebelumnya. ROI diukur dengan Earning After Tax dibagi total aktiva. EPS diukur dengan laba bersih dibagi jumlah saham beredar. Suku bunga (BI rate) diukur dengan jumlah tingkat suku bunga periode bulanan selama setahun dibagi jumlah periode waktu selama setahun. Kurs diukur dengan kurs jual ditambah kurs beli dibagi dua. Inflasi diukur dengan Indeks Harga Konsumen, yaitu harga pada periode-n dibagi harga pada periode sebelumnya dikali 100 persen. PDB diukur dengan PDB tahun ke-n dikurangan PDB tahun sebelumnya dibagi PDB tahun sebelumnya dikali 100 persen.

Metode pemilihan sampel yang digunakan dalam penelitian ini adalah purposive sampling, yaitu penentuan sampel dengan berdasarkan pada kriteria-kriteria tertentu. Sugiyono (2013:85). Kriteria-kriteria yang digunakan dalam penelitian ini sebagai berikut :

1. Emiten yang termasuk dalam kelompok Jakarta Islamic Index (JII) yang terdaftar di Bursa Efek Indonesia selama periode penelitian yaitu tahun 2008 - 2014 ( 7 tahun).

2. Menerbitkan laporan keuangan tahunan dan tersedia secara berturut-turut selama periode penelitian tahun $2008-2014$.

3. Semua data yang dibutuhkan dapat tersedia selama periode penelitian tahun 2008 2014.

Berdasarkan kriteria-kriteria tersebut diatas, maka yang dapat dijadikan sampel dalam penelitian ini berjumlah 9 emiten, yang dapat dilihat pada tabel 2 
Tabel 2. Daftar nama emiten yang termasuk Jakarta Islamic Index

Periode 2008-2014

\begin{tabular}{clc}
\hline No & Nama Perusahaan & Kode \\
\hline 1 & PT Astra Agro Lestari Tbk & AALI \\
2 & PT Antam (Persero) Tbk & ANTM \\
3 & PT International Nickel Indonesia Tbk & INCO \\
4 & PT Indocement Tunggal Prakarsa Tbk & INTP \\
5 & PT Kalbe Farma Tbk & KLBF \\
6 & PT Bukit Asam (Persero) Tbk & PTBA \\
7 & PT Semen Indonesia (Persero) Tbk & SMGR \\
8 & PT Telekomunikasi Indonesia (Persero) Tbk & TLKM \\
9 & PT Unilever Tbk & UNVR \\
\hline
\end{tabular}

Data penelitian ini merupakan data sekunder yaitu gabungan time series dan cross sectional disebut pooled data, yaitu berupa data keuangan serta berbagai informasi yang dibutuhkan dalam penelitian ini, yang diperoleh melalui website resmi di Bursa Efek Indonesia www.idx.co.id, Bank Indonesia www.bi.co.id, Yahoo Finance www.yahoofinance.com, dan masing-masing website emiten yang termasuk dalam Jakarta Islamic Index secara berturut turut selama periode 2008 - 2014. Pengumpulan data menggunakan teknik dokumentasi dengan tipe pooled data.

Teknik analisis yang digunakan untuk menguji hipotesis dengan menggunakan analisa regresi linear berganda. Dalam analisis regresi akan dicari persamaan regresi (koefisien regresi) dan nilai koefisien determinasinya.

Persamaan regresi linear berganda digunakan untuk mengetahui elastisitas variabel independen terhadap variabel dependen. Persamaan ini akan digunakan untuk melihat seberapa besar perubahan pada variabel independen yang akan mempengaruhi variabel dependennya. Persamaan yang akan dihasilkan adalah :

Return Saham $=\alpha+\mathrm{X} 1+\mathrm{X} 2+\mathrm{X} 3+\mathrm{X} 4+\mathrm{X} 5+\mathrm{X} 6+\varepsilon$
Keterangan :

$\mathrm{X} 1=$ Return on Investment

$\mathrm{X} 2=$ Earning per Share

$\mathrm{X} 3=$ Suku Bunga

$\mathrm{X} 4=$ Kurs

$\mathrm{X} 5=$ Inflasi

$\mathrm{X} 6=$ Product Domestic Bruto

$\varepsilon=$ Error Term

Berdasarkan definisi variabel penelitian di atas, maka operasionalisasi variabel penelitian ini dapat ditunjukkan pada tabel sebagai berikut: 
Tabel 3. Operasional variabel

\begin{tabular}{|c|c|c|c|c|c|}
\hline No & Variabel & Sub Variabel & Indikator & $\begin{array}{c}\text { Skala } \\
\text { Pengukuran }\end{array}$ & Referensi \\
\hline 1 & $\begin{array}{l}(\mathrm{Y})=\text { Return } \\
\text { Saham }\end{array}$ & $\begin{array}{l}\text { Return Saham } \\
\text { Realisasi }\end{array}$ & $\frac{P_{t}-P_{t-1}}{P_{t-1}}$ & Rasio & $\begin{array}{l}\text { Pinangkaan, } \\
2012\end{array}$ \\
\hline 2 & $\begin{array}{c}(\mathrm{X} 1)= \\
\text { ROI }\end{array}$ & $\begin{array}{c}\text { Return on Total } \\
\text { Asset }\end{array}$ & $\frac{\mathrm{EAT}}{\text { Total Aset }} \times 100 \%$ & Rasio & Yoga,dkk, 2014 \\
\hline 3 & $\begin{array}{c}(X 2)= \\
\text { EPS }\end{array}$ & $\begin{array}{l}\text { Jumlah saham } \\
\text { biasa yang } \\
\text { beredar }\end{array}$ & $\frac{\text { Laba Bersih }}{\text { Total Saham Beredar }}$ & Rasio & Kurniawan,2013 \\
\hline 4 & $\begin{array}{c}(\mathrm{X} 3)=\text { Suku } \\
\text { Bunga }\end{array}$ & BI Rate & $\begin{array}{c}\text { Jumlah tingkat suku } \\
\text { bunga periode bulanan } \\
\text { selama setahun } \\
\text { Jumlah periode waktu } \\
\text { selama setahun }\end{array}$ & Rasio & Neny, 2014 \\
\hline 5 & $\begin{array}{l}(\mathrm{X} 4)= \\
\text { Kurs }\end{array}$ & $\begin{array}{l}\text { Nilai tukar } \\
\text { rupiah terhadap } \\
\text { dollar US. }\end{array}$ & $\begin{array}{c}\text { Kurs Tengah }= \\
\frac{\text { Kurs Jual }+ \text { Kurs Beli }}{2}\end{array}$ & Rasio & Roshinta,2014 \\
\hline 6 & $(\mathrm{X} 5)=$ Inflasi & $\begin{array}{l}\text { Indeks Harga } \\
\text { Konsumen } \\
\text { (IHK) }\end{array}$ & $\frac{\mathrm{Pn}}{\mathrm{Po}} \times 100 \%$ & Rasio & Akhmad, 2007 \\
\hline 7 & $(\mathrm{X} 6)=\mathrm{PDB}$ & $\begin{array}{c}\text { PDB riil } \\
\text { (atas dasar } \\
\text { harga konstan) }\end{array}$ & $\begin{array}{l}\frac{\mathrm{PDB}}{\mathrm{x}}_{\mathrm{x} 100 \%}=\mathrm{PDB}_{\mathrm{x}-1} \\
\mathrm{PDB}_{\mathrm{x}-1}\end{array}$ & Rasio & Ike, 2013 \\
\hline
\end{tabular}

\section{Hasil Penelitian dan Pembahasan}

Melalui uji grafik dan uji statistik Kolmogorov-Smirnov, dapat disimpulkan dalam model regresi, variabel pengganggu atau residual memiliki distribusi normal. Hasil uji multikolinearitas terlihat bahwa model regresi dinyatakan bebas dari multikolinieritas karena memiliki nilai Tolerance di atas 0,10 dan nilai Variance Inflation Factor (VIF) dibawah 10. Artinya dalam model regresi tidak terjadi korelasi antar variabel independen. Dari hasil uji Durbin - Watson (DW) diperoleh hasil DW diatas $\mathrm{d}_{\mathrm{u}}$ dan di bawah nilai $4-\mathrm{d}_{\mathrm{u}}$. Sehingga dapat disimpulkan tidak terjadi aurokorelasi positif maupun negatif. Hasil analisis grafik scatterplot dan uji spearman's rho, diperoleh kesimpulan tidak terjadi heteroskedastisitas. Artinya dalam model regresi tidak terjadi ketidaksamaan variance dari residual satu pengamatan ke pengamatan yang lainnya.

Ketepatan fungsi regresi sampel dalam menaksir nilai aktual dapat dinilai dengan Goodness of Fit-nya. Secara statistik setidaknya ini dapat diukur dari nilai koefisien determinasinya, nilai statistik $\mathrm{t}$ dan nilai statistik F. Dari hasil penelitian didapat nilai Adjusted $\mathrm{R}^{2}$ sebesar 0,60. Hal ini berarti, sebesar 60 $\%$ variasi yang terjadi pada variabel Return Saham disebabkan oleh pengaruh ROI, EPS, suku bunga, kurs, inflasi dan PDB dan sisanya sebesar $40 \%$ dipengaruhi oleh faktor lain yang tidak dimasukan dalam model regresi, seperti : Devident Payout, CR, PER, EVA,ROE, ROA, TAT dan DER, tingkat pengangguran, transaksi berjalan dan defisit anggaran. 
Tabel 4. Hasil Uji Return Saham

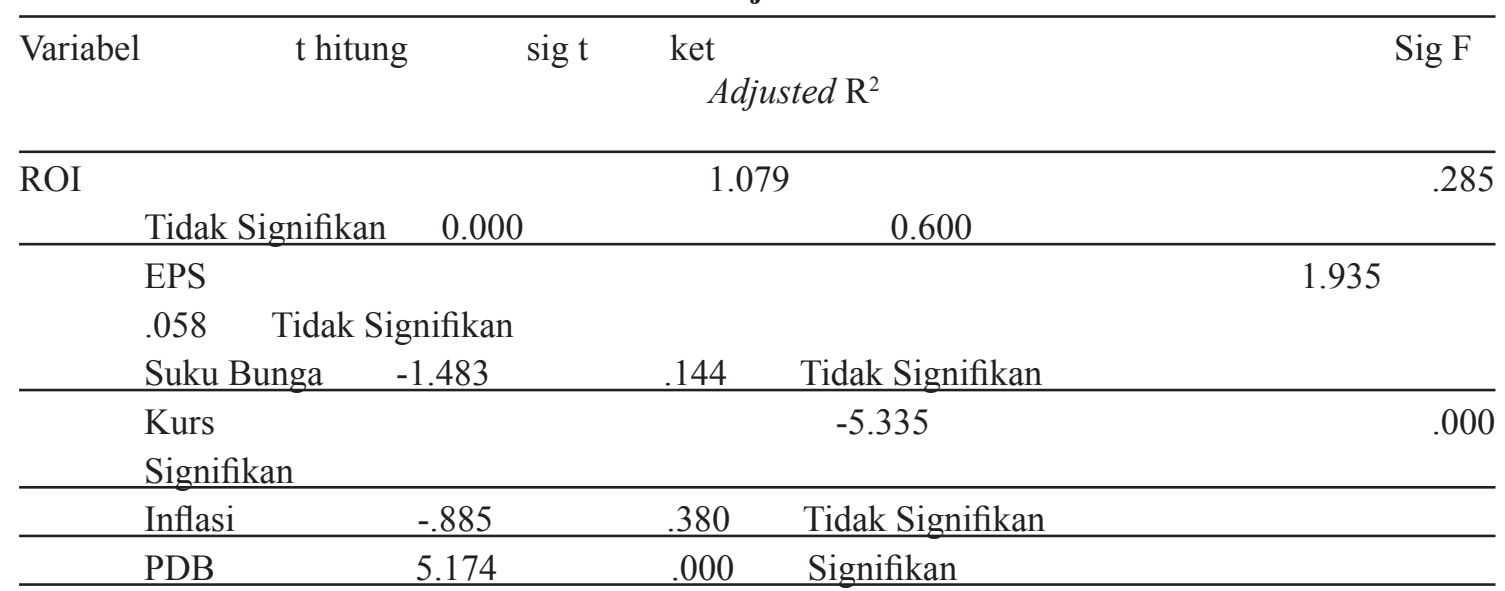

$\mathrm{H}_{1}$ : ROI berpengaruh terhadap return saham, dari hasil pengujian $\mathrm{H}_{1}$ ditolak, hal ini karena $\mathrm{t}_{\text {hitung }}<\mathrm{t}_{\text {tabel }}(1.079<2.003)$. Artinya, ROI berpengaruh terhadap return saham. Pengaruh ROI positif namuntidak signifikan terhadap return saham.

$\mathrm{H}_{2}$ : EPS berpengaruh terhadap return saham, dari hasil pengujian $\mathrm{H}_{2}$ ditolak, hal ini karenat ${ }_{\text {hitung }}<\mathrm{t}_{\text {tabel }}(1.935<2.003)$. Artinya EPSberpengaruhterhadap return saham. Pengaruh EPS positif namun tidak signifikan terhadap return saham.

$\mathrm{H}_{3}$ : Suku bunga berpengaruh terhadap return saham, dari hasil pengujian $\mathrm{H}_{3}$ ditolak, hal ini karena $\mathrm{t}_{\text {hitung }}<\mathrm{t}_{\text {tabel }}(1.483<2.003)$. Artinya suku bunga berpengaruh terhadap return saham.Pengaruh suku bunga negatif namun tidak signifikan terhadap return saham.

$\mathrm{H}_{4}$ : kurs berpengaruh terhadap return saham, hal ini dibuktikan bahwa $\mathrm{t}_{\text {hitung }}>\mathrm{t}$ tabel (5.335>2.003). Artinya, kurs berpengaruh terhadap return saham. Pengaruh Kurs negatif dan signifikan terhadap return saham.

$\mathrm{H}_{5}$ : Inflasi berpengaruh terhadap variabel return saham, dari hasil pengujian $\mathrm{H}_{5}$ ditolak, hal ini karena $\mathrm{t}$ hitung $<\mathrm{t}$ tabel $\quad(0.885<2.003)$. Artinya, inflasi berpengaruh terhadap return saham. Pengaruh Inflasi negatif namun tidak signifikan terhadap return saham.
H6 : PDB berpengaruh terhadap variabel return saham, hal ini dibuktikan bahwa $\mathrm{t}$ hitung $>\mathrm{t}_{\text {tabel }}(5.174>2.003)$. Artinya PDB berpengaruh terhadap return saham. Pengaruh PDB positif dan signifikan terhadap return saham.

H7 : ROI, EPS, suku bunga, Kurs, inflasi dan PDB secara bersama-sama (simultan) berpengaruh terhadap variabel return saham. Maka $\mathrm{H}_{7}$ Diterima, bahwa semua ROI, EPS, suku bunga, Kurs, inflasi dan PDB secara simultan berpengaruh terhadap return saham. Hal ini karena nilai $\mathrm{F}_{\text {hitung }}$ lebih besar daripada $\mathrm{F}$ tabel (16.524>2.27).

\section{Simpulan, Keterbatasan, dan Implikasi Hasil Penelitian}

Return on Investment (ROI) berpengaruh positif namun tidak signifikan terhadap return saham emiten yang terdaftar dalam Jakarta Islamic Index. Earning per Share (EPS) berpengaruh positif namun tidak signifikan terhadap return saham emiten yang terdaftar dalam Jakarta Islamic Index. Suku bunga berpengaruh negatif namun tidak signifikan terhadap return saham emiten yang terdaftar dalam Jakarta Islamic Index Kurs berpengaruh negatif dan signifikan terhadap return saham emiten yang terdaftar dalam Jakarta Islamic Index. Inflasi berpengaruh negatif namun tidak signifikan terhadap return saham emiten yang 
terdaftar dalam Jakarta Islamic Index. Product Domestic Bruto (PDB) berpengaruh positif dan signifikan terhadap return saham emiten yang terdaftar dalam Jakarta Islamic Index.

Hasil penelitian ini menyatakan bahwa variabel dependen di pengaruhi oleh variabel independen sebesar $60 \%$ dan sisanya sebesar $40 \%$ di pengaruhi oleh faktor-faktor lain yang tidak masuk dalam model penelitian ini. Penelitian ini terbatas pada saham emiten yang selama periode penelitian 2008 - 2014 berturut - turut terdaftar dalam Jakarta Islamic Index di Bursa Efek Indonesia, sehingga hanya ada 9 emiten. Penelitian ini hanya mencakup pada periode penelitian selama 7 tahun yaitu tahun 2008 - 2014 saja, sehingga data penelitian yang diperoleh masih dalam waktu terbatas dan belum dapat digeneralisasi untuk periode yang lebih panjang.

Hasil penelitian dapat dijadikan referensi agar dapat mengambil kebijakan yang akan mempengaruhi perkembangan saham syariah di Bursa Efek Indonesia, khususnya yang terdaftar di Jakarta Islamic Index. Bagi investor, hasil riset dapat digunakan sebagai pertimbangan mengambil keputusan untuk berinvestasi di pasar modal, khususnya pada saham syariah yang termasuk Jakarta Islamic Index, informasi mengenai kurs dan PDB sangat layak untuk dicermati karena secara parsial variabel kurs dan PDB berpengaruh secara signifikan terhadap return saham. Emiten dapat mencermati perilaku investor di pasar modal dengan memahami motif investor sehingga mampu menyusun strategi perusahaan untuk menarik minat para investor untuk menanamkan modalnya pada perusahaan. Penelitian yang akan datang dapat mengambil sampel seluruh saham syariah yang tergabung dalam Indeks Saham Syariah Indonesia(ISSI) sebagai obyek penelitian.

\section{Daftar Referensi}

Adjasi, Charles. Harvey, Simon K dan Agyapoing, Daniel Akwesi. The Exponential Generalised Autoregressive Conditional Heteroskedascity (EGARCH) Model Effect of Exchange Rate Volatility on the Ghana Stock Exchange. African Journal of Accounting, Economics, Finance and Banking Research, Vol. 3, No. 3, December 2008.

Agbaje, Omosola $\mathrm{M}$ and Ibrahim, Taofik Mohammed. The Relationship Between Stock Return and Inflation in Nigeria. European Scientific Journal， February 2013, Vol.9 No.4.Bank Indonesia (20032010). Laporan Perekonomian Indonesia, Bank Indonesia, Jakarta.

Beams, F. A., J. H. Anthony, R. P. Clement, dan S. H. Lowensohn, 2012, Advanced Accounting, Eleventh Edition, United States of America: Pearson Education Ltd.

Bernanke, Ben S., \& Kenneth. (2004). What explains the stock market's reaction to federal reserve policy.

Brigham, Eugene F and Joel F.Houston, 2006. Dasar-Dasar Manajemen Keuangan, alih bahasa Ali Akbar Yulianto, Buku satu, Edisi sepuluh, PT. Salemba Empat, Jakarta.

Chen., Zhang., Ganesh, 2006, "Financial Distress Predicton in China", Review of Pasific Basic Financial Markets and Policies, Vol, 9, Iss, 2, p, 317

Fuadi, Dheny Wahyu. 2013. Analisis Pengaruh Suku Bunga, Volume Perdagangan dan Kurs Terhadap Return Saham, Thesis, Universitas Diponegoro, Semarang.

Godfrey Jayne, et al. 2010. Accounting Theory, Sevent Edition. John Wiley Sons Australian Ltd.

Hamzah, Andi. Analisa Ekonomi Makro, Industri dan Karakteristik Perusahaan Terhadap Beta Saham Syariah". Jurnal Hukum Islam\&Ekonomi STAIN Malikussaleh,Lhokseumawe, Volume 1, No.2, Juli-Desember,2010. 
Hanafi Dr., M.B.A.\&Prof.Dr.Abdul Halim. 2007. Analisis Laporan Keuangan, UPP

Hartono, Jogiyanto, 2008. Teori Portofolio dan Analisis Investasi, Edisi 5, BPFE, Yogyakarta.

Hasanah, Nur Aida. 2013. Pengaruh Likuiditas Terhadap Return Saham pada Perusahaan yang Terdaftar di JII. Universitas Pendidikan Indonesia.

Hokker, Mark A. 2004. “Macroeconomic Factors and Emerging Market Equity Returns : A Bayesian Model Selection Approach". Emerging Markets Review 5 :379-387.

Huda,Nurul dan Mustafa Edwin Nasution. 2007. Investasi Pada Pasar Modal Syari'ah. Jakarta : Kencana.

Husnan, Suad. 2005. Dasar-dasar Teori Portofolio dan Analisis Sekuritas, edisi 4, Yogyakarta : UPP AMP YKPN.

Jogiyanto, H.M. (2009). Teori Portofolio dan Analisis Investasi. Edisi Ketujuh. BPFE. Yogyakarta.

Lestari, Murti. Pengaruh Variabel Makro Terhadap Return Saham Di Bursa Efek Jakarta, Pendekatan Beberapa Model, SNA VII, Solo, 15-16 September, Hal 504-513. 2005.

Meta, Rayun Sekar, 2005. Perbedaan Pengaruh Inflasi, Suku Bunga dan Nilai Tukar Rupiah/ US Dollar Terhadap Return Saham. Jurnal Ekonomi STUE Surakarta, Oktober,2005.

Mulyani, Neny. 2014. Analisis Pengaruh Inflasi, suku bunga, nilai tukar dan PDB terhadap Jakarta Islamic Index. Jurnal Bisnis dan Manajemen Eksekutif Vol.1 No.1, artikel 10. Program Pascasarjana Universitas Terbuka.

Nazwar, Chairul. 2010. Analisis Pengaruh Variabel Makro Ekonomi Trehadap Return Saham Syariah di Indonesia. Jurnal Perencanaan dan Pengembangan Wilayah.

Prihartini, Ratna. Analisis Pengaruh Inflasi, Nilai Tukar, ROA, DER, dan CR terhadap Return Saham. Tesis UNDIP. 2009.
Purnomo, R. Serfianto, Cita Yustisia Serfiyani, dan Iswi Hariyani, 2013, Pasar Uang \& Pasar Valas. Jakarta: PT. Gramedia Pustaka Utama.

Reddy, D.V. Lokeswar. 2012. Impact of Inflation and GDP on Stock Market Returns in India. International Journal of Advanced Research in Management and Social Science. Vol.1, No.6.

Sugiyono. 2013. Metode penelitian Kuantitatif Kualitatif dan $R \& D$. Bandung : Alfabeta.

Sukirno, Sadono. 2008. Makro Ekonomi. Ekonomi Teori Pengantar. Edisi 3 Jakarta : PT. Raja Grafindo Persada.

Sunardi, Harjono. 2010. Pengaruh Penilaian Kinerja dengan ROI dan EVA terhadap Return Saham pada Perusahaan yang Tergabung dalam Indeks LQ45 di Bursa Efek Indonesia. Jurnal akuntansi vol.2 no.1, hal. 70-92. Universitas Kristen Maranatha, Bandung.

Suwito, Ferry. 2012. Analisis Pengaruh BI rate, Inflasi, dan IHSG Terhadap return Saham Sektor Perbankan yang Terdaftar di Bursa Efek Indonesia (Studi Empiris Periode 2007-2011). Tesis, Fakultas Ekonomi, UI.

Suyanto.2007. Analisis Pengaruh Nilai Tukar Uang, Suku Bunga dan Inflasi Terhadap Return Saham Sektor Properti yang Tercatat di Bursa Efek Jakarta. Tesis. UNDIP.

Tangjitprom,Nopphon. Macroeconomic Factors of Emerging Stock Market: The Evidence From Thailand. Vo.3, No.2, April 2012.

Tungka, Mariesa. 2007. Analisa Pengaruh SBI, Kurs, Inflasi dan IHSG terhadap Return Saham (Studi pada saham-saham LQ45 di Bursa Efek Jakarta). Tesis. FE UI.

Ugur, S., \& Ramazan, S. 2005. Inflation, Stock Returns, and Real Activity in Turkey. The Empirical Economics Letters Vol, 4 (3), hlm.181-192.

Zulbetti, Rita. 2010. Pengaruh Rasio-Rasio dan Faktor-Faktor Makroekonomi Terhadap Return Saham. 